\title{
Evaluation the Antimicrobial Effects of Pistacia terebinthus L. and Papaver rhoeas I. Extracts Against Some Pathogen Microorganisms
}

\author{
Esin Poyrazoğlu Çoban*, Halil Biyik H, Bahadır Törün, Fatma Yaman \\ Department of Biology, Faculty of Science and Art, Adnan Menderes University, Aydin, TURKEY.
}

\begin{abstract}
In this study, the antimicrobial activity of Pistacia terebinthus L. and Papaver rhoeas $L$. extracts were tested against some pathogen microorganisms. Leaves of the plant samples were freeze-dried and powdered. Three solvents were used for extraction. The agar well diffusion method is used for the antimicrobial activities of extracts. Six different bacteria, two yeasts, and two molds were used. The extracts of $P$. terebinthus $L$. was found more effect than $P$. rhoeas $L$. extracts against tested bacteria and fungi pathogens.
\end{abstract}

Key words: Pistacia terebinthus L., Papaver rhoeas L., Folkloric Medicine, Antimicrobial Effect, Agar well diffusion method.

\section{INTRODUCTION}

Plants have been used for prevent and treat diseases in pharmacology since ancient times. ${ }^{1}$ The extracts of plants have been used for the treatments of a wide range of diseases as inflammation, diarrhea, sleep disorders and cough. ${ }^{2}$ Therefore, the use of phytochemicals for medical purposes has increased in many countries. ${ }^{3}$ Plants containing secondary metabolites such as phenolic compounds, essential oils have antibacterial, antifungal, insecticidal, acaricidal, and cytotoxic activities. ${ }^{4}$ Therefore, many researchers have been extremely studied on plants and mechanisms of action in several fields as pharmacology, pharmaceutical botany, medical and clinical microbiology, plant pathology and food preservation. ${ }^{5}$

Pistacia terebinthus L. is native to the Canary Islands and the Mediterranean region from the western regions of Morocco, and Portugal to Greece and western Turkey. ${ }^{6} P$. terebinthus produces a rich mixture of substances, including resin, essential oils, proteins, organic acids, sugars, flavonoids and tannins. $^{7}$
Papaver rhoeas L. (red poppy), which is widely distributed in Turkey, is used to make a cough syrup for children, as a tea for disturbed sleep, for pain relief, and as a sedative in folk medicine. In some regions of Turkey, a decoction prepared from red poppy petals is used for mouth inflammations in children and the infusion of the aerial parts is drunk for lowering the blood sugar level. ${ }^{8}$

\section{MATERIAL AND METHODS}

\section{Plant Materials}

The sample of leaves of Pistacia terebinthus L. and Papaver rhoeas L. were collected from Aydin province in Turkey.

\section{Preparation of plant extracts}

Leaves of the plant samples were washed with distilled water and freeze-dried. Dried leaves were powdered and 10 grams of this material was extracted separately in $150 \mathrm{~mL}$ of methanol, ethyl acetate, and boiled water for $6 \mathrm{~h}$ at Soxhlet. The extracts were concentrated and then kept at $4^{\circ} \mathrm{C} .{ }^{9}$
DOI: 10.5530/ijper.51.3s.51 Correspondence: Esin Poyrazoğlu Çoban, Department of Biology, Faculty of Science and Art, Adnan Menderes University, Aydin, TURKEY

Phone no: +90 2562182000 Email Id: epoyrazoglu@adu. edu.tr 


\section{Microorganisms and condition for cultivation}

The six bacteria, two yeasts and molds species tested as Escherichia coli ATCC 35218, Salmonella typhimurium ATCC 14028, Klebsiella pneumoniae ATCC 13882, Staphylococcus aureus ATCC 25923, Corynebacterium xerosis ATCC 373, Mycobacterium smegmatis ATCC 607, Candida utilis ATCC 9950, Candida albicans ATCC 10231, Aspergillus niger, Penicillium expansum. The bacteria, yeasts and molds were cultured in Tryptic Soy Agar (Merck) at $30-37^{\circ} \mathrm{C}$, Malt Extract Agar (Merck) at $27-30^{\circ} \mathrm{C}$ for $24 \mathrm{~h}$ and Potato Dextrose Agar (Merck) at $27^{\circ} \mathrm{C}$ for 5-7 days, respectively.

\section{Antimicrobial assays}

\section{Disc diffusion method}

Screenings for antimicrobial activities were carried out by the agar well diffusion method against test microorganisms. ${ }^{10,11}$ The inoculum size of each group of bacteria, yeast and mold were prepared by using a no. $0.5 \mathrm{McF}$ arland tube to give a concentration of $1 \times 10^{8}$ bacteria, $1 \times 10^{6}$ yeast, and $1 \times 10^{4}$ molds per milliliter. In order to test the antimicrobial activity of plants, $20 \mathrm{ml}$ of Mueller Hinton Agar (MHA) were poured in Petri dishes which were then inoculated with strains of bac- teria by taking $0.1 \mathrm{ml}$ from cell culture media. It was kept to solidify at room temperature for a while and then holes were made on top with a sterile stick. These holes were filled with $30 \mu \mathrm{L}$ of plant extracts. Then, bacterial cultures were incubated at $30-37^{\circ} \mathrm{C}$ and yeast and mold cultures were incubated at $27-30^{\circ} \mathrm{C}$ for $18-24$ h. At the end of incubation time, the diameters of the inhibition zones formed on the MHA were evaluated in millimeters. Discs of Chloramphenicol $\left(\mathrm{C}_{30}\right)$, Gentamycin $\left(\mathrm{CN}_{10}\right)$, Tetracycline $\left(\mathrm{TE}_{30}\right)$, Erythromycin $\left(\mathrm{E}_{15}\right)$, Ampicillin $\left(\mathrm{AM}_{10}\right)$, Nystatin $\left(\mathrm{NS}_{100}\right)$, and Ketoconazole $\left(\mathrm{KET}_{20}\right)$ were used as positive controls.

\section{RESULTS AND DISCUSSION}

The antimicrobial activity of methanol, ethyl acetate, and boiled distilled water of Pistacia terebinthus L. and Papaver rboeas $\mathrm{L}$. plants were investigated and the results were given in Table 1.

According to Table 1 methanol, ethyl acetate and boiled water extracts of Pistacia terebinthus L. showed antimicrobial effect against $S$. aureus ATCC 25923 and M. smegmatis ATCC 607. In addition, methanol and ethyl acetate extract of $P$. terebinthus $L$. had antimicrobial effects against

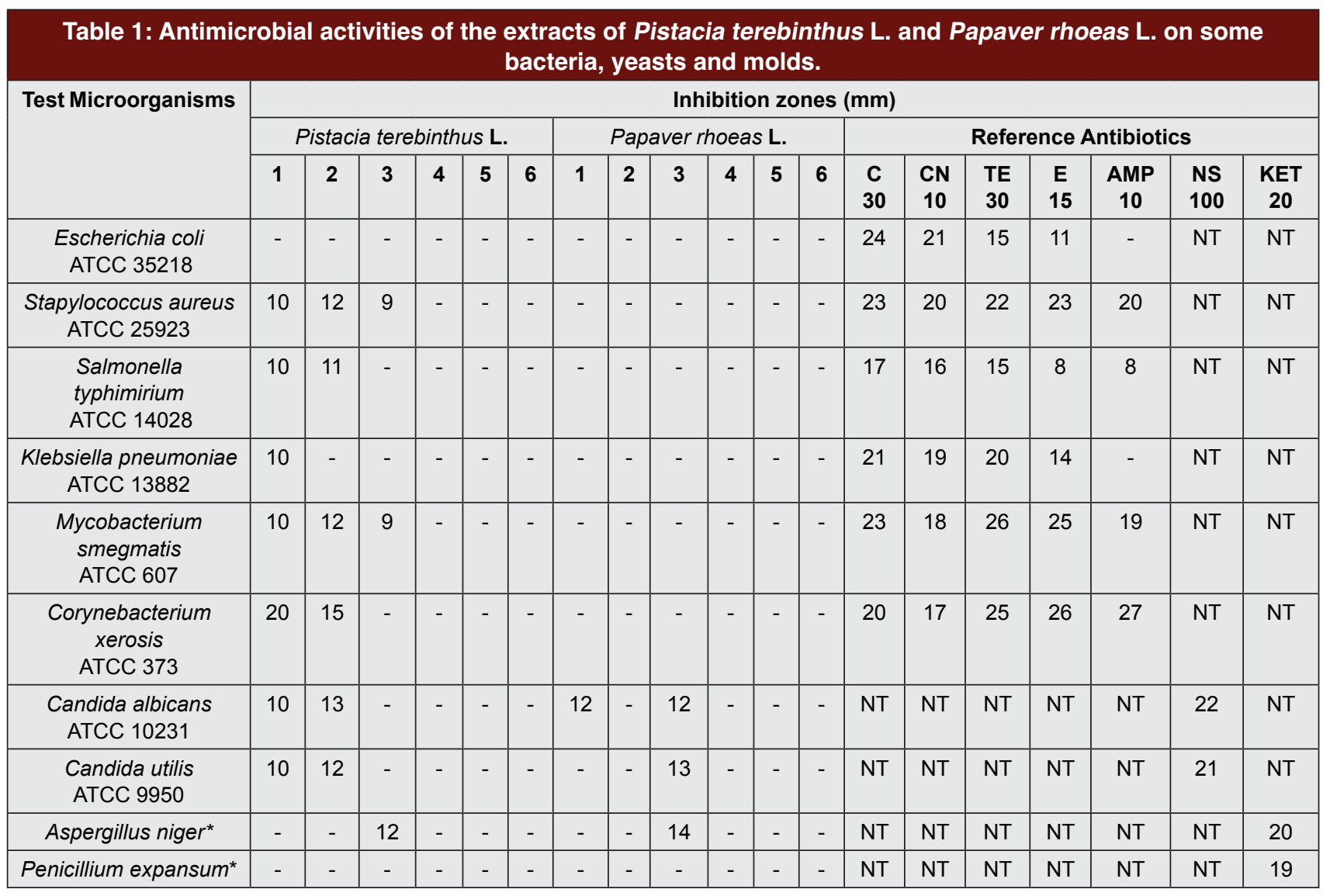


two pathogen bacteria (S. typhimirium ATCC 14028 and C. xerosis ATCC 373) and yeasts (C. albicans ATCC 10231 and C. utilis ATCC 9950). While methanol extract of $P$. terebinthus L. was only active against K. pneumoniae ATCC 13882 boiled water extract of $P$. terebinthus $\mathrm{L}$. was active against S. aureus ATCC 25923, M. smegmatis ATCC 607 and $A$. niger. Methanol and ethyl acetate extract of $P$. terebinthus $\mathrm{L}$. demonstrated only stronger activity against C. xerosis ATCC 373.

While methanol extracts of Papaver rhoeas L. was only effect against $C$. albicans ATCC 10231 boiled water extracts of $P$. rhoeas $\mathrm{L}$. showed activity against $C$. albicans ATCC 10231, C. utilis ATCC 9950 and A. niger. However, ethyl acetate extracts of $P$. rhoeas $\mathrm{L}$. did not show any antimicrobial effects against used microorganisms. None of the extracts showed antimicrobial effect against $P$. expansum.

Kostic et al. examined the methanol, ethanol and water extracts of $P$. rhoeas L. and they found that the ethanol extract of $P$. rhoeas $\mathrm{L}$. showed antimicrobial activity against the yeast Candida albicans, and all tested bacteria except Bacillus subtilis. However, methanol and water extracts of P. rhoeas L. showed less activity. ${ }^{2}$ Ünsal et al. investigated antimicrobial activity the petroleum ether, diethyl ether, chloroform, acetone and ethanol extracts of Papaver species growing in Turkey. They showed that diethyl ether, chloroform and acetone extracts of $P$. rhoeas had activity against $S$. aureus. ${ }^{8}$

1: Methanol Extract, 2: Ethyl Acetate Extract, 3: Boiled Water Extract, 4: Pure Methanol, 5: Pure Ethyl Acetate, 6:Pure Distilled Water, C30: Chloramphenicol (30 mg Oxoid), CN10: Gentamycin (10 mg Oxoid), TE30: Tetracycline (30 mg Oxoid), E15: Erythromycin (15 mg Oxoid), AMP10: Ampicillin (10 mg Oxoid), NS: Nystatin (100 mg Oxoid), KET20: Ketaconazole (20 mg Oxoid), $(*)$ : Special gift from Adnan Menderes University, Department of Biology, (-): No zone, (NT): Not tested

\section{CONCLUSION}

Pistacia terebinthus L. indicated antimicrobial effect against microorganisms more than Papaver rhoeas L. In addition, antimicrobial activity of methanol extract was higher than those of ethyl acetate and boiled water extracts. The methanol and ethyl acetate extracts of
Pistacia terebinthus reveal secondary metabolites like alkaloids, tannins, and flavonoids and these have an antimicrobial effect.

\section{ACKNOWLEDGMENT}

This work was carried out by Adnan Menderes University Biology Department Microbiology Laboratory.

\section{CONFLICT OF INTEREST}

There is no conflict of interest.

\section{ABBREVIATION USED}

MHA: Mueller Hinton Agar; C30: Chloramphenicol; CN10: Gentamycin; TE30: Tetracycline; E15: Erythromycin; AM10: Ampicillin; NS100: Nystatin; KET20: Ketoconazol.

\section{REFERENCES}

1. Sarker SD. Pharmacognosy in modern pharmacy curricula. Phcog Mag 2012;8(30):91-2.

2. Kostic DA, Mitic SS, Mitic MN, Zarubica AR, Velickovic JM, Dordevic AS, et al. Phenolic contents, antioxidant and antimicrobial activity of Papaver rhoeas L. extracts from Southeast Serbia. J Med Plants Res. 2010;4(17):1727-32.

3. Shetti S, Kumar CD, Sriwastava NK, Sharma IP. Pharmacovigilance of herbal medicines: Current state and future directions. Phcog Mag. 2011;7:69-73.

4. Malik T, Pandey DK, Roy P, Okram A. Evaluation of phytochemicals, antioxidant,

5. antibacterial and antidiabetic potential of Alpinia galanga and Eryngium foetidum plants of Manipur (India). Pharmacogn J. 2016;8(5):459-64.

6. Koubaa M, Driss D, Bouaziz F, Ghorbel RE, Chaabouni SE. Antioxidant and antimicrobial activities of solvent extract obtained from rocket (Eruca sativa L.) flowers. Free Rad Antiox. 2015;5(1):1-6.

7. Rhouma A, Daoud HB, Ghanmi S, Salah HB, Romdhane M, Demak M. Antimicrobial

8. activities of leaf extracts of Pistacia and Schinus species against some plant pathogenic fungi and bacteria. J Plant Pathol. 2009;91:339-45.

9. Boulebda N, Belkhiri A, Belfadel F, Bensegueni A, Bahri L. Dermal wound healing effect of Pistacia lentiscus fruit's fatty oil. Phcog Res. 2009;1(2):66-71.

10. Ünsal Ç, Özbek B, Sarıyar G, Mat A. Antimicrobial activity of four annual Papaver species growing in Turkey. Pharm Biol. 2009;47(1):4-6.

11. Çoban EP, Bıyık HH, Uzun C. Investigation of antimicrobial activity of some natural

12. plants which are not cultivated and are sold at bazaars in Aydın. Int $\mathrm{J}$ Natural Eng Sci. 2009;3:59-62.

13. Collins $\mathrm{CH}$, Lyne PM, Grange JM, Falkinham JO. Microbiological methods. 8th ed. London: Arnold Publishers; 2004.

14. Clinical and Laboratory Standards Institute. CLSI. M02-A12: Performance standards for antimicrobial disk susceptibility tests: Approved standard. 12th ed. Wayne: CLSI; 2015. p.1-73. 
PICTORIAL ABSTRACT

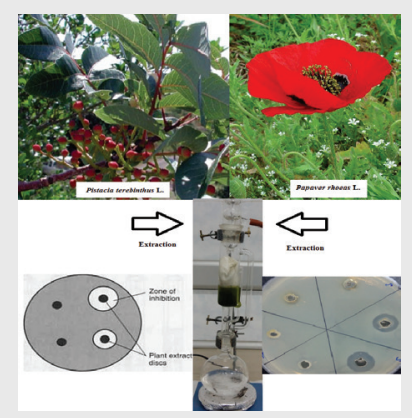

\section{SUMMARY}

- Antimicrobial effects of Pistachia terebinthis and Papaver rhoeas were studied.

- Three differen solvents and ten different microorganisms were used.

- P. terebinthus found more effective against tested microorganisms.

\section{About Authors}

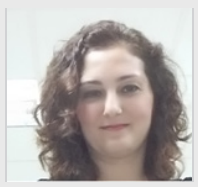

Assoc.Prof. Dr. Esin Poyrazoğlu Çoban: She complated B.Sc. in Biology at Hacettepe University. She then earned her MSc degree from the Munla University. She earned her PhD degree on Biology at Adnan Menderes University, Turkey. She is currently working at Adnan Menderes University Department of Biology as Assoc.Prof.Dr.

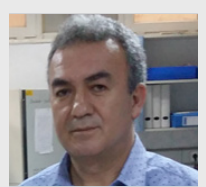

Prof.Dr. H.Halil Biyık: He complated B.Sc. in Biology at Hacettepe University. He then earned his MSc degree from the Yüzüncü Yal University. Prof. Dr. Bayak earned his PhD degree on Biology Ege University, Turkey. He is currently a full-time professor at Adnan Menderes University Department of Biology.

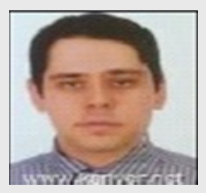

Mr. Bahadır Törün: He complated B.Sc in Biology at Ege University, Turkey. He earned his masters degree in Biology at Anadolu University, Turkey. He is now about to complate his PhD at Adnan Menderes University.

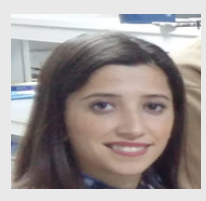

Miss. Fatma Yaman: She complated B.Sc in Biology at Adnan Menderes University, Turkey. She is currently doing her M.Sc at Adnan Menderes University.

Cite this article: Çoban EP, Biyik HH, Törün B, Yaman F. Evaluation the Antimicrobial Effects of Pistacia terebinthus L. and Papaver rhoeas L. Extracts Against Some Pathogen Microorganisms. Indian J of Pharmaceutical Education and Research. 2017;51(3)Suppl:S377-80. 